Hans Noel, Georgetown University

Eric Novotny, CRDF

Robert C. Oberst, Nebraska Wesleyan University

Laura R. Olson, Clemson University

John David Rausch, West Texas A\&M Univesity

Andrew Rehfeld, Washington University, St. Louis

Joseph W. Roberts, Roger Williams University

Daniel Rubenson, Ryerson University

Maria Rost Rublee, University of Auckland
Charles R. Venator Santiago, University of Connecticut, Storrs

Kanishkan Sathasivam, Salem State University

Carisa R. Showden, University of North Carolina, Greensboro

Charles Anthony Smith, University of California, Irvine

Jeffrey Sosland, American University Mark Souva, Florida State University Bonnie Stabile, George Mason Universit Allan C. Stam, University of Michigan Katina R. Stapleton
Jonathan R. Strand, University of Nevada, Las Vegas

Dwight V. Toavs, National Defense University

M. Stephen Weatherford, University of California, Santa Barbara

Peter W. Wielhouwer, Western Michigan University

Antoine Yoshinaka, American University

If you are interested in reviewing let us know.Contact PS@apsanet.org.

\title{
Notes from the Editor: PS: Political Science and Politics
}

\author{
PS: What You Are Reading (online)
}

Our publisher's report for PS: Political Science $\mathcal{E}$ Politics for 2011 gives us some insight into what you, our readers, are reading here in the pages of $P S$. In total, more than 101,00o readers completed full-text downloads of online articles in 2011, up nearly $30 \%$ from 2010 and $26 \%$ compared to 2009 figures. This figure only represents electronic downloads; we know that print is very important too and we hope to report on that readership in the future.

Overall, $P S$ still ranks very well against our publishers' other political science and international relations titles.

Among the organizations and institutions that downloaded the most $P S$ articles over the last year were

University of California, Riverside Libraries; Georgia State University; University of California, San Diego Libraries; University of Oxford; Balfour Library (Pitt Rivers Museum)

\section{MOST DOWN-LOADED ARTICLES IN} 2011

The five most-downloaded articles, published in any year, for PS in 2011 were:
Diascro, Jennifer Segal. 2011. "The Job Market and Placement in Political Science in 2009-10." PS: Political Science and Politics 44 (3).

Giles, Michael W., and James C. Garand. 2007. "Ranking Political Science Journals: Reputational and Citational Approaches." PS: Political Science and Politics 40 (4).

Jacobs, Lawrence R. 2010. "What Health Reform Teaches Us about American Politics." PS: Political Science and Politics 43 (4).

Leech, Beth L. 2002."Asking Questions: Techniques for Semistructured Interviews." PS: Political Science and Politics 35 (4).

Knopf, Jeffrey W. 2006. "Doing a Literature Review." PS: Political Science and Politics 39 (1).

\section{THE FIVE MOST DOWNLOADED ARTICLES FOR VOLUME 44 (2011 VOLUME)}

From our volume year recently completed in 2011, the five most downloaded articles for volume 44 are as follows:
Diasco, Jennifer Segal. 2011. “The Job Market and Placement in Political Science in 2009-10." PS: Political Science and Politics 44 (3).

Monroe, Kristen Renwick. 2011. "Ethics in an Age of Terror and Genocide: Identity and Moral Choice." PS: Political Science and Politics 44 (3).

Karpowitz, Christopher F., J. Quin Monson, Kelly D. Patterson, and Jeremy C. Pope. 2011. Tea Time in America? The Impact of the Tea Party Movement on the 2010 Midterm Elections. PS: Political Science and Politics 44 (2).

Sides, John. 2011. The Political Scientist as a Blogger. PS: Political Science and Politics 44 (2).

Perliger, Arie, and Ami Pedahzur. 2011. Social Network Analysis in the Study of Terrorism and Political Violence. PS: Political Science and Politics 44 (1).

We look forward to learning more about what you are reading in 2012.

(continued nex page) 


\section{Submissions and Decisions}

Unsolicited submissions to PS (in the Features, The Profession, and The Teacher categories) have increased over the past several years (table 1). Acceptance rates over the past several years remain fairly constant. Recently, PS eliminated its decision or action of "major revision" with decisions only as "accept," "revise and resubmit," and "reject."

In 2011, PS witnessed an increase in submissions in the teaching category, increasing from around $29 \%$ to $39 \%$ (table 3 ). $P S$ continues to include symposia in nearly every issue. As seen in table 4, published symposia average about seven per year (averaging 50 additional "articles.")

Plans for a readership survey and other evaluation of the submission process are scheduled for 2012.

Table 1.

Submissions per Year 2009-11

\begin{tabular}{lc} 
YEAR & NEW \\
\hline 2011 & 113 \\
2010 & 93 \\
2009 & 90
\end{tabular}

excludes symposia
Table 2.

\begin{tabular}{lccc} 
Outcome of the Review & Process & 2009-11(\%) \\
Outcome & $\mathbf{2 0 1 1}$ & $\mathbf{2 0 1 0}$ & $\mathbf{2 0 0 9}$ \\
\hline Accept & 30 & 27 & 24 \\
Revise and Resubmit & 31 & 29 & 24 \\
Reject or Major Revision & 39 & 44 & 52
\end{tabular}

\section{Table 3}

\section{Distribution of Papers Submitted,} 2009-2011(\%)

\begin{tabular}{|c|c|c|c|}
\hline & FEATURES & $\begin{array}{c}\text { THE } \\
\text { PROFESSION }\end{array}$ & THE TEACHER \\
\hline 2011 & 39 & 22 & 39 \\
\hline 2010 & 55 & 19 & 26 \\
\hline 2009 & 51 & 17 & 32 \\
\hline
\end{tabular}

\begin{tabular}{|c|c|c|}
\hline \multicolumn{3}{|c|}{$\begin{array}{l}\text { Table } 4 \\
\text { Symposia Published, } \\
\text { 2009-2011 }\end{array}$} \\
\hline & SYMPOSIA & $\begin{array}{c}\text { NUMBER OF } \\
\text { PAPERS }\end{array}$ \\
\hline 2011 & 6 & 41 \\
\hline 2010 & 10 & 69 \\
\hline 2009 & 6 & 49 \\
\hline
\end{tabular}

